\title{
Prevalensi dan Tingkat Infeksi Soil Transmitted Helminths Dihubungkan dengan Golongan Usia dan Jenis Kelamin pada 5 Sekolah Dasar Negeri (SDN) di Jakarta, Bekasi dan Serang (Banten)
}

\author{
Ambar Hardjanti, , a), Putri Rachmawati ${ }^{1}$, Titis Cresnaulan Desiyanti ${ }^{1}$, Rizki Fauzi Rahman ${ }^{1}$, \\ Yudi Wahyudi ${ }^{1}$, Yolanda Intan Farellina ${ }^{1}$ \\ ${ }^{1}$ Fakultas Kedokteran Universitas YARSI, Jakarta \\ a) Korespondensi Email : ambar.hardjanti@yarsi.ac.id
}

\begin{abstract}
Soil transmitted helminths (STH) infection is an infectious disease with a high prevalence, especially in developing countries. More than 1.5 billion people or $24 \%$ of the world's population are infected with STH. Indonesia is one of 11 countries in Southeast Asia which are declared as endemic for STH infection. Data on the prevalence of STH infection in children in Indonesia is still quite high, namely $60-90 \%$. Meanwhile, infections that occur continuously will reduce the quality of human resources, especially children. This study was conducted with the aim to determine the prevalence and level of STH infection in children of primary school age, and to find out whether there is a relationship between the prevalence and rate of STH infection with age and sex. This research was conducted in 5 State Elementary Schools (SD) located in Jakarta, Bekasi and Serang (Banten) in 2016. This study used analytical cross sectional method. Samples in the form of feces of students in the 5 state elementary schools. Stool samples collected were 61 from SDN Tanah Tinggi 01 Pagi Central Jakarta, 57 from SDN Pondok Bambu 04 Duren Sawit East Jakarta, 57 from SDN 02 Bantar Gebang Bekasi, 52 from SDN Cikedokan 01 Kecamatan Cikarang Barat Bekasi and 55 from SDN Cakung Serang. The samples collected had fulfilled the inclusion criteria, aged 6-12 years, had agreed and signed the informed consent sheet. Exclusion criteria included taking worm medicine 6 months earlier and not collecting feces on a predetermined day. Examination of the sample was carried out by the Kato-Katz method. The results of this study indicate that, there is only one school that is positive for helminthiasis, while 4 other schools are negative. At SDN in Serang (Banten) 9 children were found infected with STH or prevalence was $16.4 \%$ with mild intensity. The types of STH found were Ascaris lumbricoides (68.75\%), Trichuris trichiura (31.25\%), and no eggs from Necator americanus. The highest frequency occurs in children aged 6-8 years. There is no significant relationship between the prevalence and rate of STH infection with age and sex.
\end{abstract}

Keywords: Kato-Katz, Infection Level, Prevalence, Soil Trasnmitted Helminths (STH) 


\section{Pendahuluan}

Infeksi kecacingan Soil Transmitted Helminths (STH) masih merupakan masalah kesehatan dunia terutama di negara yang sedang berkembang. Infeksi kecacingan ini umumnya ditemukan di negara tropis dan subtropis yang higiene dan sanitasinya buruk (Winita dkk., 2012). Lebih dari 1,5 miliar orang atau $24 \%$ dari populasi dunia terinfeksi cacing STH, akibat kontak langsung dengan tanah. Infeksi cacing STH di Asia Tenggara, mencapai 500 juta orang dan 11 negara dikategorikan sebagai endemis dan Indonesia merupakan salah satu dari 11 negara tersebut. Lebih dari 270 juta anak-anak usia prasekolah dan lebih dari 600 juta anak usia sekolah tinggal di daerah dengan reinfeksi tinggi serta membutuhkan pengobatan dan intervensi pencegahan (WHO, 2015).

Prevalensi STH di Indonesia pada umumnya masih sangat tinggi yaitu sebesar $76,67 \%$, terutama pada golongan penduduk kurang mampu yang mempunyai risiko tinggi terjangkit penyakit ini dan $60-80 \%$ anak sekolah dasar (SD) menderita kecacingan (Martila dkk., 2015). Infeksi terbanyak disebabkan oleh Ascaris lumbricoides yakni sebesar 807 juta-1,12 milyar, Trichuris trichiura sebesar 604-795 juta dan cacing tambang 576-740 juta (CDC, 2013).

Beberapa penelitian kecacingan yang dilakukan di Jakarta antara lain menunjukkan, infeksi askariasis sebesar $62,2 \%$, dan $48 \%$ untuk trikuriasis serta $0,72 \%$ untuk cacing tambang. Anak-anak SD di daerah kumuh Jakarta 24,3\% terinfeksi cacingan dengan 87,6\% terinfeksi askariasis (Winita dkk., 2012). Demikian juga pada penelitian 2008 terhadap anak SD WGT-Taskin pada daerah kumuh di empat wilayah DKI Jakarta didapatkan infeksi askariasis dan trikuriasis di Jakarta Utara sebesar $80 \%$ dan $20 \%$, Jakarta Selatan sebesar $68,42 \%$ dan 31,58\%, Jakarta Barat sebesar $74,70 \%$ dan $25,30 \%$, sedangkan Jakarta Timur sebesar $58,33 \%$ dan $41,67 \%$ (Mardiana dan Djarismawati, 2008).

Dampak infeksi STH antara lain kehilangan zat gizi berupa kalori, protein dan darah. Infeksi kecacingan dapat terjadi pada berbagai golongan umur. Anak usia sekolah dasar merupakan golongan yang paling sering terkena infeksi cacing STH, sehingga menyebabkan gangguan pada perkembangan fisik, kecerdasan dan produktifitas kerja, dapat juga menurunkan ketahanan tubuh sehingga mudah terkena penyakit lainnya (Sungkar dan Surya, 2013).

Berdasarkan data-data tersebut di atas, maka perlu dilakukan penelitian untuk mengetahui hubungan antara prevalensi dan tingkat infeksi dengan golongan umur dan jenis kelamin serta tingkat sosial ekonomi yang berbeda khususnya pada tingkat sosial ekonomi rendah pada masyarakat di lokasi penelitian. Data prevalensi dan infeksi penting untuk tindakan pencegahan dan eliminasi kecacingan, terutama pada anak-anak usia sekolah dasar, seperti yang dilakukan pada penelitian ini.

\section{Bahan dan Metoda Penelitian}

Penelitian ini merupakan jenis penelitian analitik dengan desain cross sectional. Penelitian dilakukan pada September 2016 di 5 wilayah, yaitu : 1). SDN Tanah Tinggi 01 Pagi Jakarta Pusat, 2). SDN Pondok Bambu 04 Duren Sawit Jakarta Timur, 3). SDN 02 Bantar Gebang Bekasi, 4). SDN Cikedokan 01 Kecamatan Cikarang Barat Bekasi, 5). SDN Cakung Serang. Sampel penelitian adalah tinja dari anak-anak SD di kelima sekolah tersebut, dengan kriteria inklusi. Kriteria inklusi adalah anak sekolah usia 
6 - 12 tahun dan menyerahkan formulir persetujuan yang sudah ditandatangani orang tua (informed consent). Sedangkan kriteria eksklusi adalah anak yang tidak mengembalikan sampel tinja, meminum obat cacing 6 bulan terakhir. Besar sampel tinja pada penelitian ini dihitung berdasarkan rumus Lemeshow (Ariawan dan Besral, 2015), sehingga diperoleh besar sampel pada masing-masing lokasi adalah : 61, 57, 57, 52 dan 55 sampel tinja.

Tiga hari sebelum pengambilan sampel tinja, dilakukan penyuluhan singkat mengenai penyakit kecacingan (STH), kemudian pot tinja, formulir identitas tentang umur dan jenis kelamin serta lembar informed consent dibagikan ke seluruh anak yang hadir. Dua hari kemudian peneliti datang untuk mengumpulkan sampel tinja dan lembar formulir yang telah dibagikan sebelumnya.

Sampel tinja diperiksa di Laboratorium Parasitologi Fakultas Kedokteran Universitas YARSI, dengan metode Kato-Katz, kemudian dilihat dengan mikroskop cahaya perbesaran 400 kali (objektif 40x dan okuler 10x) untuk identifikasi dan penghitungan telur cacing STH (Ascaris lumbricoides, Trichuris trichiura, Necator americanus, Ancylostoma duodenale) yang ditemukan.

Analisis data dengan uji bivariat untuk mengetahui hubungan antara variabel bebas (jenis kelamin dan usia) dan variabel terikat (prevalensi dan tingkat infeksi STH). Uji bivariat yang digunakan adalah uji korelasi pearson yaitu analisis hubungan numerik (prevalensi) dengan numerik (umur), uji anova yaitu analisis hubungan kategorik (tingkat infeksi) dengan numerik (umur), uji beda proporsi yaitu analisis hubungan numerik (prevalensi) dengan kategorik (jenis kelamin) dan uji chi square yaitu analisis hubungan kategori (tingkat infeksi) dengan kategorik (jenis kelamin) (Sastroasmoro, 2014).

\section{Hasil Penelitian}

Penelitian dilakukan di 5 sekolah dasar yang terletak di Jakarta (2 sekolah), di Bekasi (2 sekolah) dan di Serang (1 sekolah). Kondisi sekolah tempat penelitian SD di Jakarta, cenderung lebih baik dibandingkan dengan sekolah tempat penelitian di Bekasi dan di Serang, baik dari kondisi fisik (gedung), sarana dan fasilitas kebersihan sekolah. Sebagian besar tempat bermain atau halaman sekolah di Jakarta sudah ditutup dengan semen (paving block), sementara halaman dan lingkungan di sekitar sekolah yang terletak di Bekasi dan Serang, masih berupa tanah lapang yang sebagian ditumbuhi rumput liar.

Hasil pemeriksaan sampel tinja yang berasal dari murid-murid SD kelas 1 - 6 dari lima sekolah tersebut menunjukkan prevalensi Infeksi cacing STH 100\% negatif kecacingan di empat SD dan 16,4\% positif kecacingan STH di satu SD yang diperiksa (Tabel 1).

Jenis cacing STH yang ditemukan pada sampel tinja di SDN Cakung Kecamatan Binuang Kabupaten Serang Banten adalah Ascaris lumbricoides sebesar 5.5\%, Trichuris trichiura $11 \%$ dan cacing tambang 0\% (Tabel 2) (Gambar 1). 
Tabel 1. Prevalensi Infeksi Cacing STH Pada 5 Sekolah Dasar

\begin{tabular}{lccccc}
\hline \multirow{2}{*}{\multicolumn{1}{c}{ Sekolah Dasar }} & \multicolumn{3}{c}{ Infeksi Kecacingan } & \multirow{2}{*}{ Jumlah } \\
\cline { 2 - 5 } & \multicolumn{2}{c}{ Positif } & \multicolumn{2}{c}{ Negatif } & \\
\cline { 2 - 5 } & $\mathrm{N}$ & $\%$ & $\mathrm{~N}$ & $\%$ & \\
\hline SDN 01 Tanah Tinggi & 0 & 0 & 61 & 100 & 61 \\
SDN 4 Pd Bambu & 0 & 0 & 57 & 100 & 57 \\
SDN 02 Bantargebang & 0 & 0 & 57 & 100 & 57 \\
SDN 01 Cikedokan & 0 & 0 & 52 & 100 & 52 \\
SDN Cakung Serang & 9 & 16.4 & 46 & 83.6 & 55 \\
\hline
\end{tabular}

Tabel 2. Prevalensi Infeksi Cacing Ascaris lumbricoides, Trichuris trichiura dan Cacing tambang pada 5 Sekolah Dasar

\begin{tabular}{|c|c|c|c|c|c|c|}
\hline \multirow{3}{*}{ Sekolah Dasar } & \multicolumn{6}{|c|}{ Prevalensi Infeksi Cacing STH } \\
\hline & \multicolumn{2}{|c|}{ A. lumbricoides } & \multicolumn{2}{|c|}{ T. trichiura } & \multicolumn{2}{|c|}{ Cacing tambang } \\
\hline & $\mathrm{N}$ & $\%$ & $\mathrm{~N}$ & $\%$ & $\mathrm{~N}$ & $\%$ \\
\hline SDN 01 Tanah Tinggi & 0 & 0 & 0 & 0 & 0 & 0 \\
\hline SDN 4 Pd Bambu & 0 & 0 & 0 & 0 & 0 & 0 \\
\hline SDN 02 Bantargebang & 0 & 0 & 0 & 0 & 0 & 0 \\
\hline SDN 01 Cikedokan & 0 & 0 & 0 & 0 & 0 & 0 \\
\hline SDN Cakung Serang & 3 & 5.5 & 6 & 11 & 0 & 0 \\
\hline
\end{tabular}

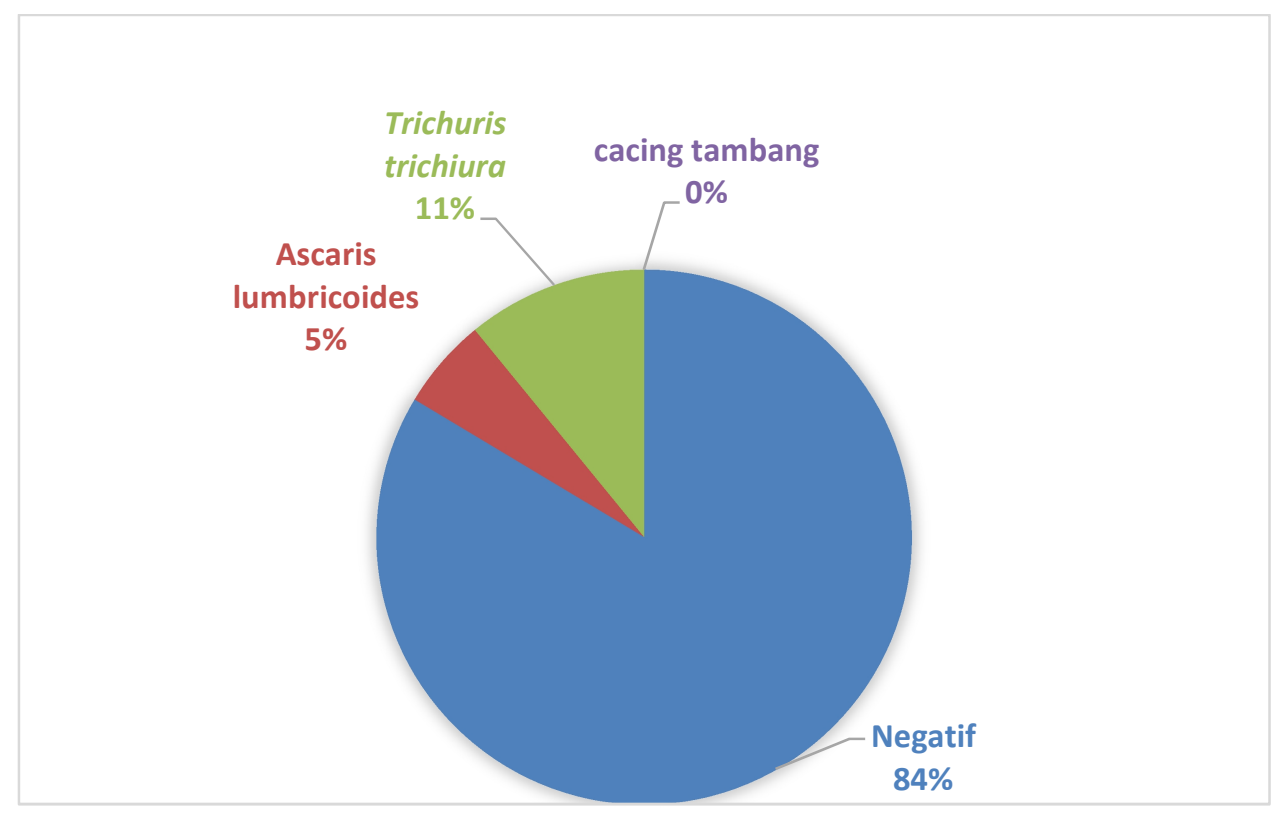

Gambar 1. Diagram Prevalensi Infeksi Cacing STH Di SDN Cakung Serang 
Hasil penelitian sesuai dengan data pola penyebaran penyakit yang didapat dari beberapa survei di Indonesia, bahwa seringkali prevalensi infeksi Ascaris lumbricoides yang tinggi disertai dengan prevalensi infeksi Trichuris trichiura yang tinggi. Penelitian yang dilakukan oleh Siti dan Ariana pada tahun 2015 menunjukkan hasil yaitu 52,72\% untuk Ascaris lumbricoides dan 42,72\% untuk Trichiuris trichiura. Sedangkan, untuk penelitian yang dilakukan pada beberapa sekolah dasar di wilayah Indonesia menunjukkan prevalensi cacing tertinggi adalah Ascaris lumbricoides (75-80\%) dan Trichuris trichiura (25-68\%) (Hairani dkk., 2014).

Tingkat infeksi kecacingan STH di SDN Cakung Serang Banten berdasarkan kriteria WHO menunjukkan hasil tingkat infeksi kecacingan STH yang ringan baik pada infeksi $A$. lumbricoides maupun T. trichiura (Tabel 3).

Rendahnya prevalensi infeksi kecacingan STH di SDN Cakung Serang dan tidak ditemukannya infeksi kecacingan STH di empat sekolah dasar lainnya, kemungkinan berhubungan dengan kecenderungan menurunnya prevalensi kecacingan STH di Jakarta yang sudah berlangsung sejak lama. Beberapa penelitian di daerah lain juga menunjukkan prevalensi dan tingkat infeksi yang semakin rendah. Penelitian yang dilakukan tahun 2010 di SDN 09 Pagi Paseban Jakarta Pusat didapatkan prevalensi Ascaris lumbricoides $8,6 \%$, Trichuris trichiura $5,4 \%$ dan cacing tambang 1,1\% (Widyasari, 2012). Penelitian Patiah pada tahun 2012, diperoleh prevalensi $A$. lumbricoides dan $T$. trichiura pada anak SDN Kalibaru 07 Jakarta Utara adalah 37,5\% dan 10,1\%. Penelitian di SDN Tarigu Cipanas Jawa Barat tahun 2012 menunjukkan prevalensi askariasis $1,1 \%$ dan trichuriasis $8,2 \%$ (Patiah, 2012).
Kecenderungan angka prevalensi dan tingkat infeksi kecacingan STH yang semakin rendah kemungkinan disebabkan tidak adanya sumber penularan dan tidak adanya kontak dengan tanah (Junus dan Marlina, 2012). Pembangunan gedung di Jakarta, termasuk gedung sekolah, dapat mengurangi tempat bermain anak dengan tanah dan memutus rantai penularan infeksi kecacingan. Pembangunan dan perbaikan sebagian besar sekolah yang meliputi perbaikan ruang kelas yang telah diberi ubin, toilet yang memungkinkan anak-anak melakukan defekasi di jamban, tersedianya air bersih, tersedianya tempat sampah dan halaman yang telah diplester mengurangi penyebaran infeksi STH yang daur hidupnya memerlukan tanah sebelum menginfeksi manusia. Kondisi fisik gedung sekolah di SDN Cakung Serang, dibandingkan dengan empat sekolah lainnya, termasuk yang paling memprihatinkan. Gedung sekolah kotor dan kurang terawat. Halaman sekolah masih berupa tanah lapang yang luas dan di sekitar sekolah tersebut merupakan daerah persawahan. Namun, di sekolah tersebut sudah tersedia jamban untuk tempat berdefekasi dan semua murid sudah menggunakan alas kaki (sepatu) sehingga, walaupun masih terdapat infeksi kecacingan STH, namun tingkat infeksinya tergolong sangat ringan.

Hubungan umur dan jenis kelamin dengan infeksi kecacingan STH disajikan pada Tabel 4 dan Tabel 5. Hasil uji $x^{2}$ menunjukkan tidak ada hubungan bermakna ( $p$ >0.05) antara prevalensi dan tingkat infeksi STH dengan umur dan jenis kelamin. Hal ini berarti baik laki-laki maupun perempuan; serta semua kelompok umur memiliki kerentanan yang sama terhadap infeksi STH. Selain itu dari hasil lembar biodata yang terkumpul, juga diperoleh beberapa data orang tua murid-murid SD tersebut seperti data jenis 
pekerjaan (Tabel 6), penghasilan (Tabel 7) dan

pendidikan (Tabel 8).

Tabel 3. Tingkat Infeksi Cacing Ascaris lumbricoides, Trichuris trichiura dan Cacing Tambang Di SDN Cakung Serang

\begin{tabular}{lccc}
\hline \multicolumn{1}{c}{ Tingkat Infeksi } & A.lumbricoides & T. trichiura & $\begin{array}{c}\text { Cacing } \\
\text { Tambang }\end{array}$ \\
\hline Ringan & 3 & 6 & 0 \\
Sedang & - & - & - \\
Berat & - & - & - \\
\hline
\end{tabular}

Tabel 4. Hubungan Antara Infeksi STH Dan Umur

\begin{tabular}{ccc}
\hline Kelompok Umur & \multicolumn{2}{c}{ Infeksi STH } \\
\cline { 2 - 3 } & Positif & Negatif \\
\hline $6-8$ & 5 & 20 \\
$9-12$ & 4 & 26 \\
Total & 9 & 46 \\
\hline
\end{tabular}

Tabel 5. Hubungan Antara Infeksi STH Dan Jenis Kelamin

\begin{tabular}{ccc}
\hline Jenis Kelamin & \multicolumn{2}{c}{ Infeksi STH } \\
\cline { 2 - 3 } & Positif & Negatif \\
\hline Laki-laki & 4 & 20 \\
Perempuan & 5 & 26 \\
Total & 9 & 46 \\
\hline
\end{tabular}


Pekerjaan orang tua berkaitan dengan cara orang tua mendidik anak, dalam hal ini agar anak dapat berperilaku sehat, sehingga dapat terhindar dari infeksi kecacingan. Berdasarkan Tabel 6, dapat disimpulkan bahwa mayoritas pekerjaan orang tua adalah sebagai ibu rumah tangga. Ibu rumah tangga mempunyai peranan yang sangat penting dalam mendidik dan membiasakan anak agar dapat menjaga kebersihan diri dan lingkungan di sekitarnya. Infeksi kecacingan dapat dicegah dengan cara menerapkan hidup bersih dan sehat, seperti cuci tangan sebelum makan, defekasi di jamban, menggunakan alas kaki dan mandi teratur. Perilaku ini dapat memutus daur hidup cacing STH (Pohan, 2009; Hadidjaja dan Margono, 2011).

Tabel 6. Jenis Pekerjaan Orang tua

\begin{tabular}{|c|c|c|c|c|c|c|c|c|c|c|}
\hline \multirow{3}{*}{ Pekerjaan } & \multicolumn{10}{|c|}{ Sekolah Dasar } \\
\hline & \multicolumn{2}{|c|}{$\begin{array}{c}\text { SDN } 01 \\
\text { Tanah Tinggi }\end{array}$} & \multicolumn{2}{|c|}{$\begin{array}{l}\text { SDN } 4 \text { Pondok } \\
\text { Bambu }\end{array}$} & \multicolumn{2}{|c|}{$\begin{array}{c}\text { SDN } 02 \\
\text { Bantargebang }\end{array}$} & \multicolumn{2}{|c|}{$\begin{array}{c}\text { SDN } 01 \\
\text { Cikedokan }\end{array}$} & \multicolumn{2}{|c|}{$\begin{array}{c}\text { SDN Cakung } \\
\text { Serang }\end{array}$} \\
\hline & $\mathrm{N}$ & $\%$ & $\mathrm{~N}$ & $\%$ & $\mathrm{~N}$ & $\%$ & $\mathrm{~N}$ & $\%$ & $\mathrm{~N}$ & $\%$ \\
\hline Ibu Rumah Tangga & 43 & 69 & 17 & 30 & 8 & 14 & 8 & 15 & 14 & 25 \\
\hline Karyawan & 6 & 10 & 8 & 14 & 19 & 33 & 14 & 27 & 3 & 5 \\
\hline Buruh & 3 & 5 & 8 & 14 & 4 & 7 & 5 & 10 & 18 & 33 \\
\hline Wiraswasta & 3 & 5 & 11 & 19 & 21 & 36 & 15 & 29 & 13 & 24 \\
\hline Pedagang & 3 & 5 & 0 & 0 & 1 & 2 & 7 & 13 & 0 & 0 \\
\hline Guru & 1 & 2 & 0 & 0 & 0 & 0 & 1 & 2 & 0 & 0 \\
\hline Petani & 0 & 0 & 0 & 0 & 0 & 0 & 1 & 2 & 5 & 9 \\
\hline Kuli & 0 & 0 & 0 & 0 & 2 & 4 & 0 & 0 & 1 & 1 \\
\hline Satpam & 1 & 2 & 0 & 0 & 0 & 0 & 1 & 2 & 0 & 0 \\
\hline Supir & 1 & 2 & 0 & 0 & 2 & 4 & 0 & 0 & 1 & 1 \\
\hline Lain-lain & & & 13 & 23 & & & & & & \\
\hline Jumlah & 61 & 100 & 57 & 100 & 57 & 100 & 52 & 100 & 55 & 100 \\
\hline
\end{tabular}

Tabel 7. Penghasilan Orang tua

\begin{tabular}{lccccccc}
\hline \multirow{3}{*}{\multicolumn{1}{c}{ Sekolah Dasar }} & \multicolumn{7}{c}{ Kelompok Penghasilan } \\
\cline { 2 - 7 } & \multicolumn{1}{c}{ Rp. 1,65 juta } & \multicolumn{1}{c}{$1,65-3,30$ juta } & \multicolumn{2}{c}{$>3,30$ juta } & \multirow{2}{*}{ Jumlah } \\
\cline { 2 - 7 } & $\mathrm{N}$ & $\%$ & $\mathrm{~N}$ & $\%$ & $\mathrm{~N}$ & $\%$ & \\
\hline SDN 01 Tanah Tinggi & 33 & 54 & 28 & 46 & 0 & 0 & 61 \\
SDN 4 Pd Bambu & 26 & 46 & 22 & 39 & 9 & 16 & 57 \\
SDN 02 Bantargebang & 13 & 23 & 35 & 61 & 9 & 16 & 57 \\
SDN 01 Cikedokan & 25 & 48 & 20 & 38 & 7 & 14 & 52 \\
SDN Cakung Serang & 35 & 63 & 17 & 31 & 3 & 6 & 55 \\
\hline
\end{tabular}




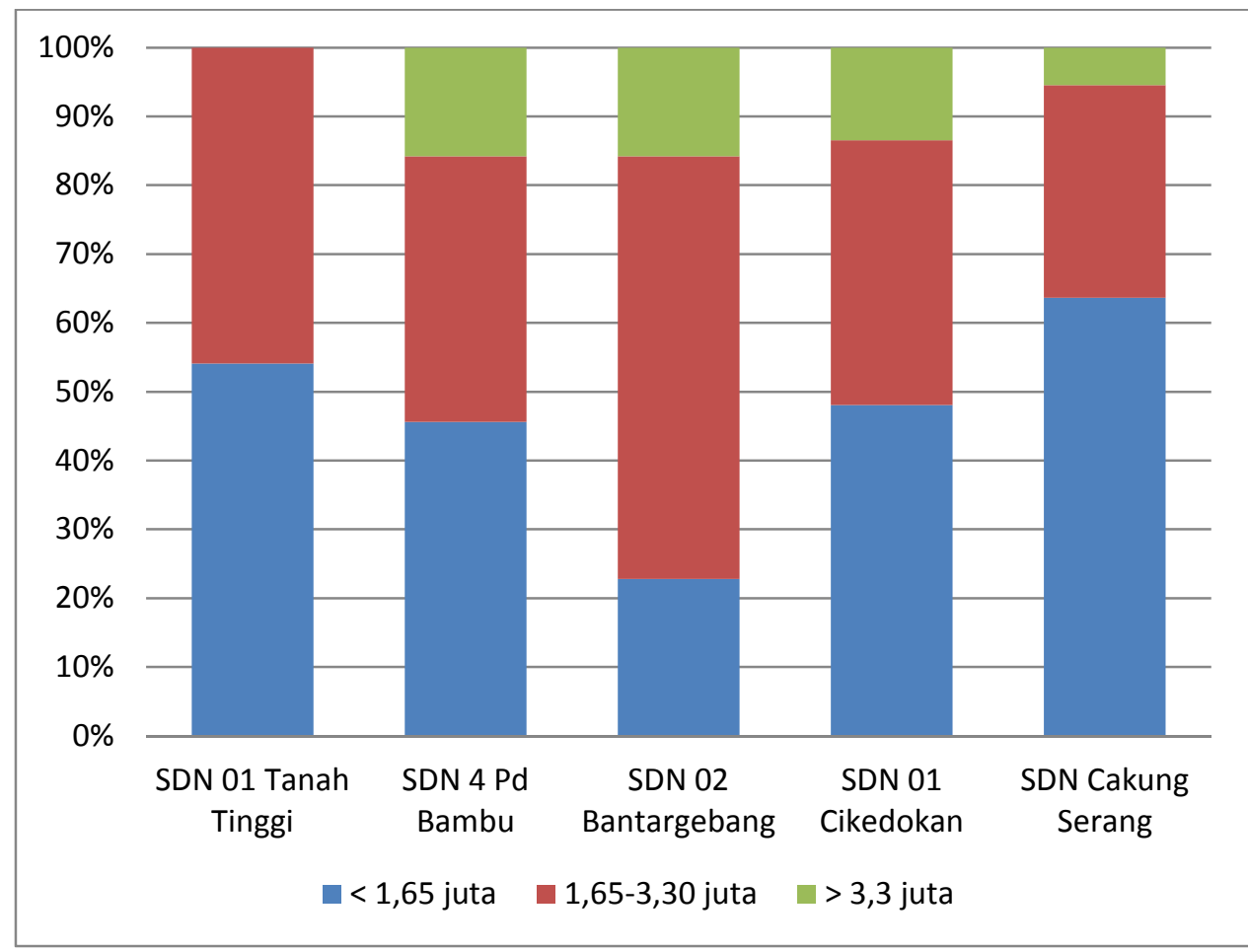

Gambar 2. Stacked Bar Penghasilan Orang Tua

Tabel 8. Pendidikan Orang tua

\begin{tabular}{|c|c|c|c|c|c|c|c|c|c|c|c|}
\hline \multirow{3}{*}{ Sekolah Dasar } & \multicolumn{11}{|c|}{ Pendidikan Tertinggi } \\
\hline & \multicolumn{2}{|c|}{ SD } & \multicolumn{2}{|c|}{ SMP } & \multicolumn{2}{|c|}{ SMA/SMK } & \multicolumn{2}{|c|}{ Diploma } & \multicolumn{2}{|c|}{ Sarjana } & \multirow{2}{*}{ Jumlah } \\
\hline & $\mathrm{N}$ & $\%$ & $\mathrm{~N}$ & $\%$ & $\mathrm{~N}$ & $\%$ & $\mathrm{~N}$ & $\%$ & $\mathrm{~N}$ & $\%$ & \\
\hline SDN 01 Tanah Tinggi & 19 & 31 & 22 & 36 & 18 & 30 & 2 & 3 & 0 & 0 & 61 \\
\hline SDN 4 Pd Bambu & 12 & 21 & 13 & 23 & 28 & 49 & 4 & 7 & 0 & 0 & 57 \\
\hline SDN 02 Bantargebang & 6 & 10 & 20 & 35 & 26 & 46 & 1 & 2 & 4 & 7 & 57 \\
\hline SDN 01 Cikedokan & 12 & 34 & 19 & 38 & 13 & 26 & 3 & 2 & 0 & 0 & 52 \\
\hline SDN Cakung Serang & 28 & 51 & 17 & 31 & 10 & 18 & 0 & 0 & 0 & 0 & 55 \\
\hline
\end{tabular}

Berdasarkan Tabel 7 dan Gambar 2, terlihat bahwa penghasilan orang tua murid di SDN Cakung Serang cenderung lebih rendah dibanding keempat SDN yang lain. Sebanyak $63 \%$ orang tua murid di SDN Cakung Serang memiliki penghasilan di bawah Rp. 1.6500 .000 dibanding orang tua di keempat SDN yang lain (23-54\%). Namun, dengan banyaknya informasi atau pun penyuluhan STH dari berbagai sumber, rendahnya penghasilan ini tidak lagi menjadi kendala dalam hal berperilaku bersih dan sehat. Munculnya kesadaran akan hal ini, tentu saja erat kaitannya dengan pencegahan infeksi kecacingan terutama pada anak-anak. Hal ini menjadi salah satu faktor penyebab tidak ada atau rendahnya infeksi kecacingan STH di kelima sekolah dasar yang diteliti. 
Tabel 8 dan Gambar 3 menunjukkan bahwa sebagian besar (51\%) orang tua di SDN Cakung Serang cenderung memiliki pendidikan yang lebih rendah dibanding empat SDN yang lain (10-31\%). Tingkat pendidikan orang tua diharapkan sebanding dengan pengetahuan orang tua mengenai kebiasaan hidup bersih dan sehat. Pengetahuan yang dimiliki orang tua diharapkan dapat berperan penting dalam mencegah terjadinya infeksi pada anak, salah satunya terhadap infeksi cacing STH.

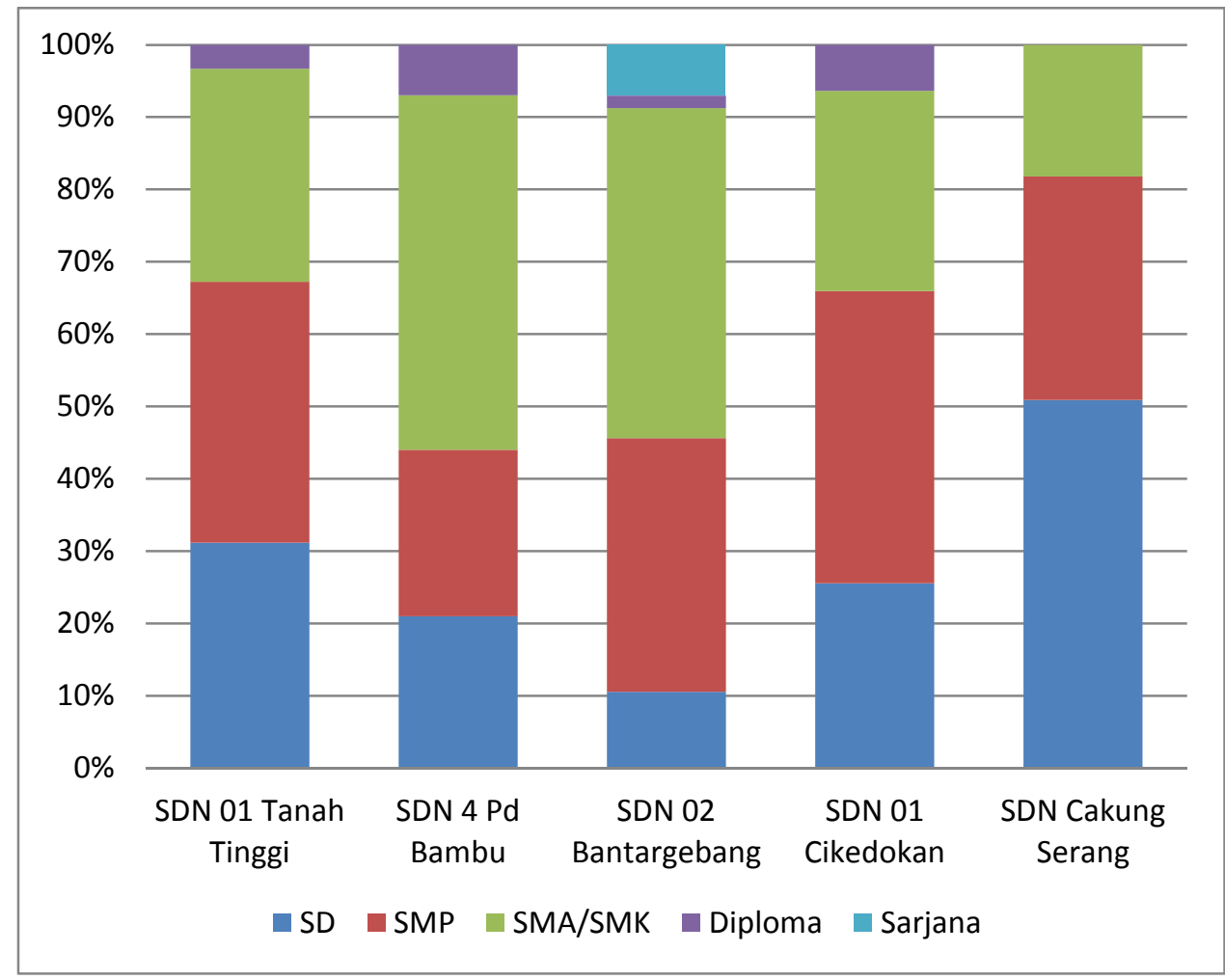

Gambar 3. Stacked Bar Pendidikan Orang Tua

\section{Simpulan}

Berdasarkan hasil penelitian yang telah dilakukan di lima Sekolah Dasar, maka dapat disimpulkan tidak terdapat infeksi cacing STH di empat sekolah yang ada di Jakarta dan Bekasi, namun terdapat infeksi kecacingan di SD Cakung Binuang Serang Banten. Prevalensi infeksi cacing STH di SD Cakung adalah 9 dari 55 anak (prevalensi 16.4\%), yang terdiri dari 4 anak laki-laki dan 5 anak perempuan dengan tingkat infeksi ringan. Umur yang terinfeksi kecacingan terdapat baik pada kelompok umur 6-8 tahun (5 anak) maupun 9-12 tahun (4 anak).
Tidak terdapat hubungan antara prevalensi infeksi STH dengan umur dan jenis kelamin.

\section{Daftar Pustaka}

Ariawan, I dan Besral 2015. Perhitungan Besar Sampel. Viewed 27 Januari 2016, from https://www.risbinkes.litbang.depkes.go.id CDC 2013. Soil Transmitted Helmints. Viewed 10 Mei 2016, from https://www.cdc.gov Hadidjaja, $\mathrm{P}$ dan Margono, SS. Dasar Parasitologi Klinik Indonesia. 2011. P. 125-42 
Hairani, B., Juhairiyah dan Waris, L. 2014. Prevalensi Soil Transmitted Helminths (sth) pada Anak Sekolah Dasar di Kecamatan Malinau Kota Kabupaten Malinau Provinsi Kalimantan Timur. Jurnal Buski, Vol. 5(1). Kalimantan, 43-48. 3 March, viewed 3 February 2017, from

https://www.ejournal.litbang.depkes.go.id/index.p hp/buski/article/download/3614/3564

Junus dan Marlina, L. 2012. Hubungan Pendidikan Formal, Pengetahuan Ibu Dan Sosial Ekonomi Terhadap Infeksi Soil Transmitted Helminths Pada Anak Sekolah Dasar Di Kecamatan Seluma Timur Kabupaten Seluma Bengkulu. Jurnal Ekologi Kesehatan, 11(1), 33-39. Viewed 28 Agustus 2016, from https://ejournal.litbang.depkes.go.id/index. php/jek/article/download/3824/367

Mardiana dan Djarismawati 2008. Prevalensi Cacing Usus pada Murid Sekolah Dasar Wajib Belajar Pelayanan Gerakan Terpadu Pengentasan Kemiskinan Daerah kumuh di Wilayah DKI Jakarta. Jurnal Ekologi Kesehatan, Vol. 7(2). 2 Agustus, viewed 13 Agustus 2016, from https://ejournal.litbang.depkes.go.id/index. php/jek/article/view/1653

Patiah, P. 2012. Prevalensi, Intensitas Infeksi dan Faktor Risiko Soil Transmitted Helminths pada Anak Sekolah Dasar dan Anggota Keluarga di Jakarta dan Cipanas. Jakarta: Fakultas Kedokteran Program Studi Biomedik. P. 40

Pohan, HT. Penyakit Cacing Yang Ditularkan Melalui Tanah. In : Sudoyo, AW., Setiyohadi, B. dkk., editors. Buku Ajar Imu Penyakit Dalam. Edisi V. Jakarta : Interna Publishing; 2009. P 2938-42
Sastroasmoro, S. 2014. Dasar-dasar Metode Penelitian Klinis Edisi Kelima. Jakarta: Sagung Seto. P. 130

Siti, U.C., dan Ariana, S. Analisis Resiko Soil Transmitted Helminths di Sekolah Dasar di Kecamatan Padaherang Kabupaten Ciamis, Jawa Barat. 2015. KESMAS Journal; Vol 9(1): 37-44. Available from http://journal.uad.ac.id

Sungkar, S dan Surya, D. Efektivitas Penyuluhan terhadap Tingkat Pengetahuan Guru SD di Jakarta Mengenai Pencegahan Cacingan, Tahun 2011. Jurnal Program Studi Pendidikan Dokter, Fakultas Kedokteran Universitas Indonesia Departemen Parasitologi, Fakultas Kedokteran Universitas Indonesia, Jakarta. Vol.1(3). Jakarta: Desember, 2013.

Widyasari, A. 2012. Hubungan Infeksi Kecacingan yang ditransmisikan Melalui Tanah (Soil Transmitted Helminth) dengan Jenis Kelamin, Kelas dan Jumlah Anggota Keluarga pada Siswa SDN 09 Pagi Paseban Tahun 2010. Jakarta : Fakultas Kedokteran Universitas Indonesia. P. 27

Winita, R., Mulyati dan Astuty, H. Upaya Pemberantasan Kecacingan di Sekolah Dasar. Makara, Kesehatan. Vol.16(2) : 6571. Desember 2012

World Health Organization (WHO). Intestinal Worms, Soil Transmitted Helminths. Geneva; 2015. 